Winter 1998

\title{
Gothic Thermidor: The Bals des victimes, the Fantastic, and the Production of Historical Knowledge in Post-Terror France
}

Ronald Schechter

College of William and Mary, rbsche@wm.edu

Follow this and additional works at: https://scholarworks.wm.edu/aspubs

Part of the European History Commons

\section{Recommended Citation}

Schechter, Ronald, Gothic Thermidor: The Bals des victimes, the Fantastic, and the Production of Historical Knowledge in Post-Terror France (1998). Representations, 61, 78-94.

$10.2307 / 2902948$

This Article is brought to you for free and open access by the Arts and Sciences at W\&M ScholarWorks. It has been accepted for inclusion in Arts \& Sciences Articles by an authorized administrator of W\&M ScholarWorks. For more information, please contact scholarworks@wm.edu. 
Journal Title: Representations. ${ }^{\star \star \star}$ need scan from print for repository ${ }^{\star \star \star}$

Vol: 61

No:

Month:

Year: Winter 1998

Pages: $78-94+$ title \& verso

Article Title: Gothic Thermidor: The Bals des victimes, the Fantastic, and the Production of Historical Knowledge in PostTerror France

Article Author: Schechter, Ron

ISSN: 0734-6018

Item Barcode: 32777020968066

Bin/location: R20M24S17T05 CCR20M24S17T05 CC

ILLiad Transaction Number: 448286 


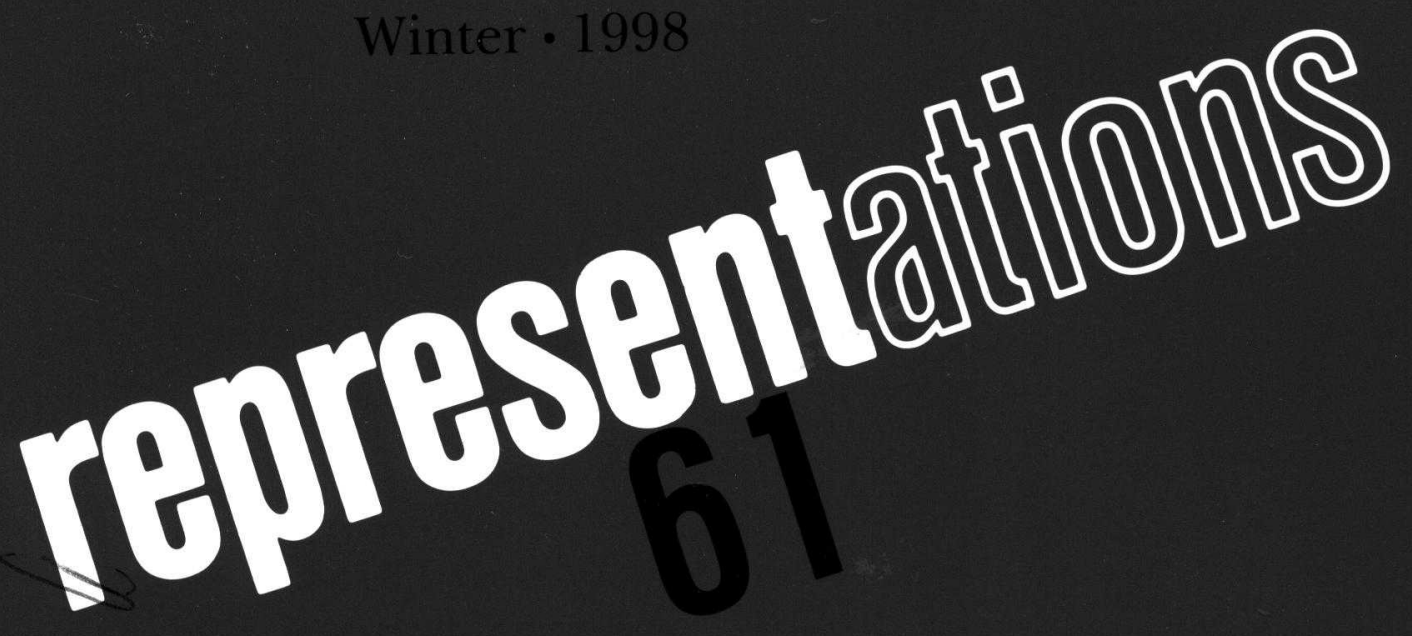

SPECIAL ISSUE

Practices of Enlightenment

Edited by Carla Hesse

CARLA HESSE

Introduction

JOHN BENDER

Enlightenment Fiction and

the Scientific Hypothesis

JONATHAN SHEEHAN

Enlightenment Details: Theology,

Natural History, and the Letter $h$

ELIZABETH J. MACARTHUR

Embodying the Public Sphere:

Censorship and the Reading Subject

in Beaumarchais's Mariage de Figaro

RONALD SCHECHTER

Gothic Thermidor: The Bals des victimes,

the Fantastic, and the Production of

Historical Knowledge in Post-Terror France

ROLF REICHARDT

Light Against Darkness

University of California Press 
Representations (ISSN 0734-6018) is published quarterly for the subscription prices given below by the University of California Press, 2120 Berkeley Way,

EDITORIAL BOARD

Berkeley, CA 94720. Periodicals postage paid at Berkeley, CA, and additional mailing offices. POSTMASTER: Send address changes to Representations, University of California Press, Berkeley, CA 94720. Canadian GST \#R122058662.

Address books for review and manuscripts for submission to the Editors, REPRESEnTATIONS, 322 Wheeler Hall, University of California, Berkeley, CA 94720. Address subscription orders, changes of address, and business correspondence (including requests for permissions and advertising orders) to Representations, University of California Press, 2120 Berkeley Way, Berkeley, CA 94720 . For classroom use see copying notice below.

Subscriptions to REPRESENTATIONS in the USA are $\$ 36.00$ a year to individuals, $\$ 95.00$ a year to institutions, and $\$ 24.00$ a year to students (enclose a copy of valid ID). Subscribers elsewhere should add $\$ 6.00$ postage. Subscriptions beginning with subsequent issues can be anticipated within 3 months. Back issues are $\$ 9.50$ to individuals and $\$ 26.00$ to institutions. Domestic claims for nonreceipt of issues should be made within 90 days of the month of publication, overseas claims within 180 days. Thereafter, the regular back issue rate will be charged for replacement. Overseas delivery is not guaranteed.

Copying notice: Authorization to photocopy items for internal or personal use, or the internal or personal use of specific clients, is granted by the Regents of the University of California for libraries and other users registered with the Copyright Clearance Center (CCC) Transactional Reporting Service, provided that the base fee of $\$ 1.00$ per copy is paid directly to CCC, 222 Rosewood Drive, Danvers, MA 01923. For permission to photocopy materials for classroom use, call CCC's APS Customer Service Department at 508750-8400 (FAX 508-750-4744).

(7) This journal is printed on recycled paper meeting the minimum requirements of American National Standard for Information SciencesPermanence of Paper for Printed Library Materials, ANSI Z39.48-1992.

- 1998 The Regents of the University of California. Printed in U.S.A. $\Theta$

REPRESENTATIONS gratefully acknowledges the generous support of the Czeslaw Milosz Fund for Distinguished Faculty in the Humanities, a gift of Reita and James R. Bell.
Stephen Greenblatt

Co-Chair

Carla Hesse

Co-ChaIR

Paul Alpers

Svetlana Alpers

Shadi Bartsch

Katherine Bergeron

T. J. Clark

Carol J. Clover

Catherine Gallagher

Darcy Grimaldo Grigsby

Timothy Hampton

Steven Justice

Kerwin Klein

Thomas Laqueur

Samuel Otter

Robert Post

Michael Rogin

Mark B. Sandberg

Randolph Starn

Anne M. Wagner

Bernard Williams

\section{R. Howard Bloch Steven Knapp \\ CORRESPONDING EDITORS}

\author{
Associate Editor \\ Jean Day \\ Editorial Assistants \\ Sara Guyer \\ Andrew Lakoff
}

VISIT REPRESENTATIONS

ON THE WORLD WIDE WEB AT

http://socrates.berkeley.edu:7000/

LOOK FOR

information about present and past issues

subscription and submission details

links to related sites 


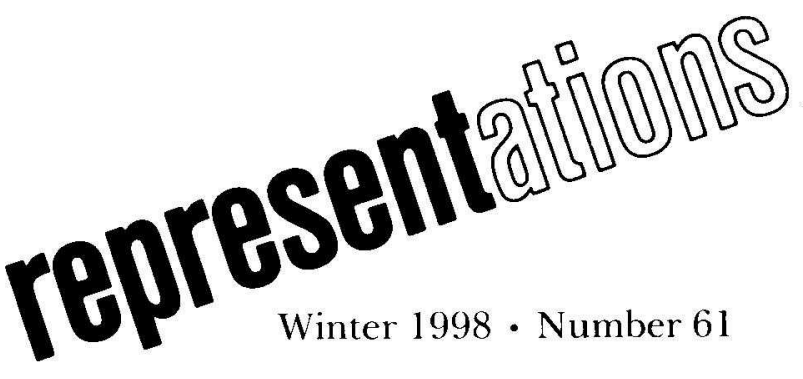

SPECIAL ISSUE

Practices of Enlightenment

Edited by Carla Hesse

CARLA HESSE

Introduction PAGE 1

JOHN BENDER

Enlightenment Fiction and

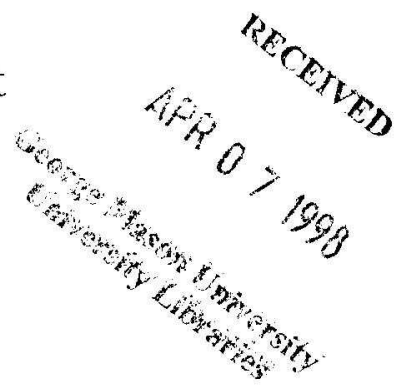

the Scientific Hypothesis PAGE 6

JONATHAN SHEEHAN

Enlightenment Details: Theology,

Natural History, and the Letter $h$ PAGE 29

ELIZABETH J. MACARTHUR

Embodying the Public Sphere:

Censorship and the Reading Subject

in Beaumarchais's Mariage de Figaro PAGE 57

RONALD SCHECHTER

Gothic Thermidor: The Bals des victimes, the Fantastic, and the Production of

Historical Knowledge in Post-Terror France PAGE 78

ROLF REICHARDT

Light Against Darkness: The Visual

Representations of a Central

Enlightenment Concept PAGE 95

University of California Press 
Contributors to this issue:

CARLA HESSE is Professor of History at the University of California at Berkeley and Co-Chair of the editorial board of Representations. Her publications include Publishing and Cultural Politics in Revolutionary Paris, 1789-1810 (1991); Culture and Identity in Early Modern Europe, 1500-1800; and numerous articles on the history of publishing, literary culture, and libraries.

JOHN BENDER is Professor of English and Comparative Literature at Stanford University. He is the author of Imagining the Penitentiary: Fiction and the Architecture of Mind in Eighteenth-Century England, which was awarded the Gottschalk Prize by the American Society for Eighteenth-Century Studies. He is the co-editor of The Ends of Rhetoric: History, Theory, Practice and Chronotypes: The Construction of Time and of Henry Fielding's Tom Jones. He is now at work on a book about science and the novel in the eighteenth century.

JONATHAN SHEEHAN is a doctoral candidate in the Department of History at the University of California at Berkeley. Currently a fellow at the Townsend Center for the Humanities at Berkeley, he is writing on translations of the Bible and philological humanism in Enlightenment Germany. His E-mail address is jsheehan (usocrates.berkeley.edu.

ELIZABETH J. MacARTHUR, Associate Professor of French at the University of California at Santa Barbara, is the author of Extravagant Narratives: Closure and Dynamics in the Epistolary Form and co-translator of Michel Serres's Le contrat naturel. The article on Beaumarchais in this issue is part of her current book project on the embodied public sphere in late-eighteenth-century France, which also includes chapters on Diderot, Rousseau, Mercier, and Mme Roland.

RONALD SCHECHTER is Assistant Professor of History at the College of William and Mary and the author of "Translating the Marseillaise: Biblical Republicanism and the Emancipation of Jews in Revolutionary France," in Past and Present 143. He is currently working on the book Jews and Frenchmen: Perceptions and Presentations, 1715-1815.

ROI.F REICHARDT is the head of the French Department of the University Library at Mainz. He specializes in the cultural history of early modern Europe and the French Revolution and has edited exposition catalogs on the symbolism of the Bastille and French caricatures. He is also the founder and co-editor of the Handbuch politisch-sozialer Grundbegriffe in Frankreich, 1680-1820 and the author of numerous publications on historical prints in France and Germany. His most recent work, scheduled for publication in 1998, concerns the French Revolution and European political culture. 


\section{Gothic Thermidor: \\ The Bals des victimes, the \\ Fantastic, and the Production of Historical Knowledge in Post-Terror France}

IT IS COMMON KNOWLEDGE THAT shortly after the fall of Robespierre relatives of persons guillotined during the Terror gathered at "victims' balls." Historians of all political sympathies, of at least three nationalities, and across a period of more than a century and a half have commented on the curious dancing societies to which only "victims," or more properly speaking, surviving relations of victims, were admitted. Thomas Carlyle wrote in his French Revolution:

Among the innumerable kinds of Balls [in post-Terror Paris], let the hasty reader mark only this single one: the kind they call Victim Balls, Bals à Victime. The dancers, in choice costume, have all crape round the left arm: to be admitted, it needs that you be a Victime; that you have lost a relative under the Terror. Peace to the Dead; let us dance to their memory! For in all ways one must dance. ${ }^{1}$

Carlyle's compatriot Archibald Alison described the dancing society as "one of the most fashionable and brilliant assemblies" in Thermidorian Paris. He observed that "between the country-dances, [the dancers] said, 'We dance on the tombs," " and noted that "a favourite dress for the hair was adopted from the way in which [that of guillotine victims] had been arranged immediately before execution."

The story of the victims' balls, however, was not merely English currency. French historians repeatedly commented on the bizarre institution as well. In the late 1830s Théophile Lavallée wrote in his Histoire des français of the "bals des victimes, at which one danced in mourning clothes, and to which only individuals whose relatives had perished on the scaffold were admitted," and attributed this strange practice to the anti-Jacobin street-fighting dandies known as the jeunesse dorée. ${ }^{3}$ In 1855 Jules Michelet denounced what he viewed as the hypocrisy of the dancing societies, "where impudent luxury rolled in the orgy of its false mourning," and a few years later the socialist historian Louis Blanc condemned the "impious lightness" with which survivors "parodied" their relatives' executions. ${ }^{4}$ Ed- 
mond and Jules Goncourt were more sympathetic, seeing in the macabre institution an understandable release from the fear, sorrow, and anger produced by the Terror:

France is dancing.

She has been dancing since Thermidor. . . . she dances to avenge, she dances to forget! Between her bloody past and her dark future, she dances! Scarcely saved from the guillotine, she dances. ... France, still bloodied and all ruined, turns and pirouettes and spins about in an immense and mad farandole. ${ }^{5}$

Though the Goncourt brothers were given to suspiciously poetic depictions of history, the same cannot be said of the great positivist historian of the Third Republic, Alphonse Aulard, who nevertheless confirmed the existence of the victims' balls, "to which no one was admitted unless some relative had been guillotined."6 His rival, the socialist Albert Mathiez, disagreed with him on nearly every point, but concurred on the existence of the bal des victimes. ${ }^{7}$ Louis Madelin included an account of the victims' ball in his Révolution française. ${ }^{8}$ Postwar historians, including Norman Hampson, André Castelot, Denis Richet, and François Furet, have been equally certain that the victims' balls took place. ${ }^{9}$

Despite the common agreement of historians over a period of more than 160 years, there is little if any contemporary evidence that the bals des victimes in fact existed. It is telling in this respect that Aulard, famously scrupulous about the importance of documentation in historiography, failed to cite a source for his description of the balls. ${ }^{10}$ Indeed, even his massive anthology of documents, Paris pendant la réaction thermidorienne et sous le directoire, contains nothing to confirm the existence of the victims' balls. The five-volume collection consists largely of reports by police spies who, in search of evidence of subversive activity as well as antigovernment moods, recorded the most minute details of Parisian social life during the five years between the fall of Robespierre and the rise of Napoleon. Surely they would have reported the bals des victimes had they been aware of them. ${ }^{11}$ The Goncourt brothers, by contrast, did cite a contemporary source, the so-called petites affiches or the daily newspaper specializing in entertainment and cultural events, as evidence of the existence of the bals des victimes. But a thorough reading of the petites affiches throughout the Thermidorian period yields not a single reference to the notorious institution. One finds many advertisements for balls, but none for victims' balls. ${ }^{12}$

The earliest reference to the victims' balls that $I$ have been able to find is from Le spectateur du nord, an émigré newspaper in Hamburg, which published a letter of 29 March, 1797 criticizing the "frivolity" of "people who find a ball more interesting than a primary assembly, and of whom there is nothing left to say when one recalls their bals de victimes." 13 Yet this claim is doubly suspect, since it betrays an obvious political bias and was "reported" from faraway Hamburg. The editors 
of the Parisian theater journal, Le censeur dramatique, did include a brief note on the victims' balls in the winter of 1797 , but they wrote of them in the past tense, suggesting that they no longer existed. ${ }^{14}$ Three years later Louis-Sébastien Mercier described the "bizarre amusement" in his Nouveau Paris, but he too wrote of it in the past tense..$^{15}$ Otherwise one searches in vain for contemporary or near contemporary mention of the notorious balls. A "tableau des bals d'hiver" for the winter of 1798-99 was silent on the subject, and a ten-page preview of subscription balls for the 1799-1800 season had nothing to say about bals des victimes. ${ }^{16}$ Even die-hard opponents of the jeunesse dorée, whom later commentators would associate with the victims' balls, appear to have said nothing of them, despite the obvious political mileage of linking them to such reprehensible conduct, and in 1797 a Parisian satire on the jeunesse dorée lacked all restraint when parodying its members, but said nothing about victims' balls. ${ }^{17}$

How did a marginal rumor hardly mentioned by contemporaries enter the historiographical canon as an unquestioned fact? How did it achieve the status of common knowledge? In order to answer these questions it is necessary to examine the memoirs of individuals who "recalled" the victims' balls for posterity. From the mid-1820s until midcentury the bals des victimes were a staple of memoir literature on the period of Thermidor and the Directory. ${ }^{18}$ In 1825 General Ségur remembered "those dances that were impudently called bals des victimes." ${ }^{19}$ In 1827 Antoine Caillot recalled "the opening of a ball to which only persons mourning one or several relatives who had died on the scaffold were admitted." ${ }^{0}$ That same year Empress Josephine's biographer M. A. Le Normand remembered the time when "the bals à la victime were much in vogue, and everyday one heard the most piquant anecdotes about what had happened" the night before. ${ }^{21}$ In 1833 Charles Nodier, whose account served as the basis for Louis Blanc's subsequent claims, described the "bal des victimes, to which a woman was not admitted unless someone in her family had perished on the scaffold."22 That same year the actor AntoineVincent Arnault reported the dancing festivities and noted the "victims' coiffure" that dancers wore in imitation of the final haircut performed by the executioner at the guillotine. ${ }^{23}$ In 1838 Laure Junot, duchesse d'Abrantès, one of the few who claimed actually to have been present at the victims' balls, gave a detailed and relatively sympathetic account of their origin at the Hôtel Richelieu in January $1795 .{ }^{24}$ The 1840 s saw a number of similar accounts. The comte d'Allonville speculated on which balls in Paris were actually bals des victimes. ${ }^{25}$ Georges Duval included a lengthy description of the institution in his Souvenirs thermidoriens, and embellished on earlier portrayals by claiming that participants at the balls performed, as an "atrocious joke," a salut à la victime in which one greeted one's dancing partner not with a gentle nod, but with a sudden jerk of the head, "in imitation of the condemned" at the moment of decapitation. ${ }^{26}$ The baronne de Vaudey remembered the bal des victimes as "one of the balls that brought together all of the elegant monde," and the Englishman J.G. Millingen recalled "this strange 
assembly" in his Recollections of Republican France. ${ }^{27}$ Finally, the famous actor François-Joseph Talma mentioned the bals des victimes in his memoirs, published in $1850 .{ }^{28}$

It is easy enough to discredit much of the memoir literature on the victims' balls. For example, Nodier was fourteen or fifteen years old in 1795 and in hiding, probably in the provinces, due to his father's dangerous Terrorist connections and his own role as the Jacobin martyr Joseph Bara in a republican pageant. ${ }^{29}$ Besides, he was notorious among contemporaries for having lied about his "Girondin" past. ${ }^{30}$ D'Abrantès is equally suspect. She wrote voluminous memoirs throughout the $1830 \mathrm{~s}$, possibly to support her opium habit, and the internal contradictions of her own memoirs make them hard to believe. ${ }^{31}$ She attributed the founding of the bal des victimes in January 1795 to a royalist widow of the battle of Quiberon, though that battle did not take place until June, and elsewhere reported the unlikely story that Napoleon had unsuccessfully courted her mother for marriage.32 Duval has been aptly called a "completely trustworthy liar" for his consistent repetition of popular rumors, and his account of the victims' ball is even less credible in that he admitted reporting it secondhand. Other memoirs are hardly more reliable. ${ }^{3.3}$ They were written decades after the events described, and it is not entirely cynical to suspect that authors-or their relations-were hoping to profit from their longevity by selling recollections of a turbulent and compelling period. The point of discrediting these accounts is not to call into question the rigor of historians (and perhaps other memorialists) who subsequently relied on them, but to suggest that something other than the actual plausibility of the victims' ball stories led to their frequent repetition. Some other factors must have been figured into the persistence of this particular rumor in the French collective memory.

It would be tempting to offer a purely political explanation of the remarkable strength of this "memory." After all, a great deal of recent scholarship has emphasized the political goals that collective memory of historical events, real or mythical, has frequently served. Historians have repeatedly shown how political communities sustained themselves through commemoration, either in the form of consciously constructed festivals and monuments or the often unconscious repetition of ideologically coded language. ${ }^{34}$ To be sure, the story of the victims' ball was not politically innocent, and could be marshaled to partisan causes. For the émigrés from Hamburg cited above, the victims' ball stood for the apathy of fashionable Parisians in the face of a bad republican government. For the republican Mercier the victims' ball represented the "vain efforts of the aristocracy to form new cabals." ${ }_{55}$ Duval, though a staunch anti-Jacobin and former member of the jeunesse dorée, similarly wrote that participants at the balls "belonged in general to the high aristocracy," and "wanted neither to dance with the others nor as the others. They needed a ball that the vulgar could not penetrate." ${ }^{36}$ In 1806 the English propagandist Stewarton spread the rumor of the "balls of the revolution- 
ary victims" to discredit the French enemy. He sarcastically reported that "Madame Buonaparte, then the disconsolate widow of the guillotined Viscount de Beauharnois, was one of the principal directresses of the ball," and even more improbably claimed that one floor above Napoleon frequented a "Ball of the Executioners," to which no one was admitted who "could not prove himself to have committed since the revolution some crimes deserving the gallows should royalty be restored." ${ }^{37}$ Though less hostile, Carlyle, Alison, and Millingen may implicitly have used the victims' balls to indict the French as a frivolous people, and even a number of French memorialists saw the institution as emblematic of French national character. ${ }^{38}$

Yet if the victims' ball story had political potential, it was a remarkably nonpartisan memory. Mercier was a republican who later supported Napoleon. D'Abrantès was an unrepentant Bonapartist. Nodier was a political chameleon, who had been a Jacobin, a legitimist, then finally a self-proclaimed "Girondist" and supporter of the July Monarchy at the time when he published his memoirs. Duval glorified his early days as an anti-Jacobin street-fighter, Caillot was a legitimist, and all but D'Abrantès found the bal des victimes reprehensible. It is also significant that recollections of the victims' balls are absent from the memoirs of politicians. One looks in vain for descriptions in the memoirs of Paul Barras, Lazare Carnot, Louis Marie de La Revellière-Lépeaux, Joseph Fouché, Jean-Baptiste Louvet, Bertrand Barère, Henri Grégoire, or Antoine-Claire Thibaudeau, all of whom were politically active and in Paris during the time when the victims' balls supposedly took place.$^{39}$ Finally, a purely political interpretation would be hard pressed to account for the sudden increase in the story's popularity in the mid-1820s and its repetition in the 1830s and 1840s, when both aristocrats and former members of the jeunesse dorée, the supposed frequenters of the victims' balls, were declining in political importance.

Yet the delayed popularity of the victims' ball stories makes sense if one considers that with the passage of time the French needed vivid, eloquent images that epitomized an otherwise chaotic period that was overshadowed by the more recent and memorable age of Napoleon. They needed an aide-mémoire, or what Maurice Halbwachs called a "gripping abbreviation," a "summary of collective reflections and feelings" that "projects a singularly vivid image on the screen of an obscure and unclear past." ${ }^{40}$ That the victims' ball served as this abbreviation is suggested in the language of Nodier, who assured his reader that "what everyone will tell you of that time is that there was a bal des victimes," as if no other fact summarized as completely the aftermath of the Terror. ${ }^{41}$ Similarly, Caillot saw in the $\mathrm{Bal}$ aux victimes an "eminently picturesque expression, which gives the most exact idea of this careless, frivolous and inconsistent character" of French society after Thermidor. ${ }^{42}$

Specifically, the victims' balls recalled the real fact that despite the fall of 
Robespierre and ending of the Terror, the republican regime was left with a legacy of numerous discontents in French society. Le Normand portrayed this situation by recounting the following anecdote:

One of the directors said jokingly to his associates, "What do you want[?] One must let [the regime's opponents] engage in politics in their way; as long as it is only a matter of songs, rhymes, charades, even enigmas, one must give them this sort of reparation, to console them at least for the properties of which they have been despoiled. Let us not trouble their sweet pleasures; let them numb their grief in the midst of feasts and bals à la victime. They will find in them a diversion and a sort of compensation for the countless evils that they have suffered. ${ }^{43}$

Thus Le Normand's benevolent Director offered a "safety valve" interpretation of carnivalesque protest avant la lettre. Though commentators differed on the seriousness of such "charades" and "enigmas," they all seem to have seen them as emblematic of some class of adversaries to the state. Just who this class comprised was unclear. Mercier and Duval assumed that they were former nobles, and Le Normand suggested as much by referring to the confiscated property of the regime's opponents, the shared implication being that the bal des victimes constituted the revenge of an aristocracy reconstituting itself as a class of "victims." Yet most memorialists reported that "victims" of any class were admitted to the balls provided that they could prove themselves related to a guillotined person, and Le Normand herself painted a picture of class mixing rather than distinction when she wrote, "Nothing was more common after the day of 9 Thermidor than to meet at the same party the accuser and the accused, the hangman with his victim, the assassin with the daughter of the man whose life he had cut." 44 Of the victims' balls in particular she wrote, "Often the son of a conventionnel of 1793 danced the pas de schal with the daughter of an émigré marquis. The most ferocious men satisfied themselves by waltzing with the niece of a former seigneur." ${ }^{45}$ This memory, however embellished, corresponded to the real social confusion of the Thermidorian period, when nouveaux riches speculators and their families could masquerade as highborn ladies and gentlemen, and genuine ci-devant nobles fell into poverty or prudently adopted a modest appearance. Moreover, this class confusion is mirrored in the fact that some writers believed the victimes to have been former aristocrats, while others associated them with the jeunesse dorée, consisting primarily of the lower-middle-class children of clerks and shopkeepers who merely affected aristocratic manners. ${ }^{46}$

In addition to class confusion, the period of Thermidor and the Directory was marked by gender confusion. Following the masculinized Reign of Terror came a return of women to political and cultural prominence. ${ }^{47}$ Madame Tallien, mistress to Director Barras, Madame de Récamier, and Napoleon's wife Josephine Bonaparte hosted salons that were considered de rigueur for ambitious politicians and leaders of the Parisian social scene. Whether the real political influence of 
women increased is debatable, but it is a cultural fact that they were perceived to be powerful. Fashion mirrored this perception, as women wore their hair short in imitation of the Roman emperor Titus while men grew their hair long, either hanging down as "spaniel's ears" or tied up in a bun. The gender reversals of the period help to explain why so many commentators saw the bal des victimes as primarily a women's affair. Etienne de Jouy wrote, "The victimes had their ball where the same women whose heroism had been admired a few weeks before only distinguished themselves now by the bizarrerie of their attire and the inconceivable thoughtlessness (légèreté) of their conduct." Yet he said nothing of the men. ${ }^{48}$ Nodier similarly offered a gendered picture when he summarized the balls as places "where a woman was not admitted if someone in her family had not perished on the scaffold," and noted that "the required dress of a danseuse was that in which her mother or sister had fallen under the hand of the executioner, that is to say the red shawl and her hair cut level with her neck."49 D'Abrantès recalled the bals des victimes as the invention of widows whose husbands had died fighting for the counter-Revolution, ${ }^{50}$ and Duval associated them with the return of feminine charm after the Terror:

Thus there was nothing more gay at the Bal des Victimes than all those young persons who competed there in grace, attire and beauty; for one of the happy fruits of the Thermidorian reaction was the resurrection of the dressing-table [la toilette]. The women then took pleasure in compensating themselves for the obligation that they had had [during the Terror] of renouncing hats, velvet, satin and all the apparatus of feminine flirtatiousness [la coquetterie féminine] by throwing themselves ardently into all the excesses of the most extravagant, and for some I add, the most indecent luxury. ${ }^{51}$

Finally, the period following Robespierre's death was marked by psychological confusion. The sudden end of the Terror provoked collective joy, yet the recent deaths of so many people required grief. The image of the victims' ball eloquently expressed the cohabitation of these two contradictory emotions. For Caillot it was "a bizarre expression which contains two unsociable ideas, that of pleasure and that of affliction!" Yet it was precisely this synthesis that made it "an eminently picturesque expression" capable of capturing the mood of post-Terror Paris. ${ }^{52}$ Experiencing pleasure soon after the death of a relative violated the accepted rules of mourning, and again the image of the victims' ball epitomized this transgression. Mercier asked rhetorically,

Will posterity believe that persons whose relatives died on the scaffold did not institute days of solemn and common affliction during which, assembled in mourning clothing, they would attest to their grief over such cruel, such recent losses, but instead [instituted] days of dancing where the point was to waltz, drink and eat to one's heart's content[? $]^{53}$

Though less indignant than Mercier, the editors of the Censeur dramatique showed similar concern over the importance of complete mourning, and reported that only those whose relatives had died more than six months previously could be 
admitted into the bal des victimes. ${ }^{54}$ Nevertheless, other commentators failed to report this ruleand in general regarded the infamous festivities as clear violations of accepted mourning practices. Arnault compared the premature celebrations to the funerary rites of "certain countries, where every burial is followed by an orgy, where joy abruptly follows tears and manifests itself in the midst of mourning." ${ }^{55}$ Others characterized the violation in terms strikingly similar to Georges Bataille's definition of taboo as decomposition, the liminal state between wet and dry. ${ }^{56}$ The editors of the Spectateur $d u$ nord associated the victims' balls with the transgression of celebrating during the dangerous period of bodily decay, "And it is to dance that the relatives of these unfortunate [guillotined persons] come together, on ground still reeking of their blood!!!"57 Duval similarly reported the dancing mania as a violation of the taboo on celebrating before the dead had dried:

Scarcely had the scaffolds been overturned, the cesspool of the barrière du Trône still showed passersby its large and yawning chasm from the bottom of which putrid miasmas continued to be exhaled into the air and infect the neighborhood; the surrounding ground had not yet finished absorbing all the human blood in which it had been steeped for ... two months, and already balls were being organized at all points of the capital; from all points of the capital the joyous sounds of the clarinet, the violin, the drum ... convoked the survivors of the terror to the pleasures of dance..$^{58}$

Elsewhere Duval strikingly denounced the black humor of the salut à la victime as an "infamous insult to the still bleeding shades of [the dancers'] fathers." ${ }^{59}$ Writing on the dancing mania of Thermidor in general, the baronne de Vaudey similarly found it "a subject of continual astonishment" that "after all the blood with which our squares had just been soaked, the relatives, the friends and even the simple acquaintances of the victims could take part in these pleasures." "6o

One recollection of Parisian merrymaking in general and the victims' ball in particular epitomizes much of the imagery discussed so far. Napoleon's General Ségur depicted French légèreté, political and social confusion, the unhealthy mixture of pleasure and grief, and the pollution caused by violation of mourning taboos amidst a bloodscape of still decomposing victims:

At that time Bonaparte lived in Paris, as we all did, in the midst of extraordinary confusion to which French thoughtlessness (légèreté) gave the bizarre spectacle: a mad and unfitting reaction of the joyous, gracious and gallant manners of the monarchy mixed with revolutionary carelessness and indecent fashions, along with the horror of brutal and barbarian manners following the republican terror; a formless mixture of pleasure and pain; a shocking contrast of joy and mourning, feast and famine; a hardly honorable association finally of the old and the new regime, carrying on the warm and bloody ashes of so many eviscerated relations and in the midst of incarcerations and even executions which still took place, a recurring and ceaseless need for concerts, songs, tender romances and those dances that were impudently called bals des victimes! ${ }^{61}$

In addition to their mnemonic value as "gripping abbreviations" of the confusing period following Thermidor, victims' ball stories bore striking resem- 
blances to contemporary fiction. Victor Hugo, Alexandre Dumas, Jules Janin, Eugene Sue, and Washington Irving (translated into French by Petrus Borel) frequently indulged in Guillotinromantik, lingering over the horrors of decapitation, and even the realist Stendhal dwelled on the haunting execution of Julien in $L e$ rouge et le noir. ${ }^{62}$ Nodier himself, who as an adolescent had witnessed the guillotine in action, included graphic depictions of beheadings in his own stories "Smarra" (1821), "L'histoire d'Hélène Gillet" (1832), and "Jean-François les Bas-Bleus" (1833). ${ }^{63}$ Irving's Tales of a Traveller (1824), Hugo's Dernier jour d'un condamné (1829), Janin's Ane mort (1829), and Dumas's Femme au collier de velours (1849) all contain fantastic narratives about victims returning (or apparently returning) from the dead to haunt the living. ${ }^{64}$ While accounts of the bals des victimes did not literally involve resuscitated corpses, they frequently included depictions of persons who imitated the dead through haircut, dress, or gesture and more generally suggested the haunting presence of the guillotine and its victims.

Another significant resemblance between victims' ball narratives and popular fantastic literature is the strong element of liminality. Popular themes of the fantastic writers included vampires, werewolves, and other monsters inhabiting threshold regions between life and death, and mixing the attributes of the living and the dead. Victims' ball stories not only featured characters, the victimes, who appeared to inhabit a realm between life and death, but, as noted previously, also alluded to the still decomposing remains of the executed, the dangerous miasmas associated with them, and analogous liminal themes such as incomplete mourning, the unhealthful mixture of joy and grief, and the dangerous mixing of classes, manners, and political legacies. It is perhaps not accidental that Nodier both "recalled" the bal des victimes for posterity and wrote stories about vampires. ${ }^{65}$ In a sense both belong to the same literary style.

The fantastic traits of the victims' ball stories also help to explain the sudden increase in the stories in the $1820 \mathrm{~s}$, since it was during this decade, shortly after the successes of John Polidori's Vampyre and Mary Shelley's Frankenstein in Britain, that the fantastic emerged as a popular genre in France. That tales of the bals des victimes appealed to a fantastic imagination is moreover suggested by the fact that some French writers associated them with the practice of mystification. Tzvetan Todorov has defined the fantastic in terms of the reader's (or protagonist's) uncertainty as to whether the bizarre scenes depicted have a natural or supernatural explanation. ${ }^{66}$ Thus the phenomenon of mystification, or apparent conjuring of the dead through tricks unknown to the observer, is a natural theme for fantastic literature. ${ }^{67}$ The editors of Charivari linked mystification and the collective memory of the victims' balls when, because of the presence of the type of reactionaries presumably long dead, they mocked a state ball in Spain in 1844 as "encore un bal des victimes," and compared the event to the infamous performances of the eighteenth-century mystificateur and self-proclaimed necromancer Count Alessandro di Cagliostro. ${ }^{68}$ 
Mystification also played a prominent role in the 1869 fantastic novel Le bal des victimes by Ponson du Terrail. In some ways Ponson's depiction of post-Terror dancing recalls that of the memorialists discussed earlier and bears a striking resemblance to that of the Goncourt brothers:

The crowd thronged the streets.

Motley, bizarre, bustling, joyous, noisy crowd, the crowd that goes dancing.

For they danced everywhere then; they danced out of pleasure, out of necessity, out of duty.

Long enough had France had her feet in the blood, her head broken by political preoccupations, her stomach disordered by hunger.

France did not want any more courts, hangmen, guillotines, massacres, but balls and shows.

Here comes the hour of the reaction, the reaction of pleasure.

They are ruined, but they will dance. ${ }^{69}$

Yet Ponson differed from the memorialists and historians discussed earlier in that he described festivities at which executed persons appeared truly to have returned from the dead. Early in the novel a man claiming to be a former marquis appears at a party hosted by the Director Barras. He is covered with tattoos depicting executions and symbols of the Revolution, claims to have been executed during the Terror, and accuses Barras, who had formerly supported the terrorists, of being an assassin. When Barras scoffs at these claims, the man washes himself off and is recognized by a horrified guest who claims to have been his executioner. Later Barras is abducted by royalists, including the self-proclaimed marquis, and taken to a secret bal des victimes. There he encounters people who appear to have been executed as well-they wear red ribbons around their necks to simulate prior decapitation - but then learns that all of his "hosts" are merely relatives of executed persons, and that the "marquis" is actually the brother of a real executed marquis, whom he resembles physically. ${ }^{70}$ The association between the victims' balls and mystification appeared as late as 1909 , when an author claimed that at the end of 1795 Grimod de la Reynière, who in fact was a famous mystificateur, "had the idea of the Bal des Victimes, which, by simple mystification, became a real success. “71

To be sure, neither the romantic preoccupation with the guillotine nor the monstrous themes of fantastic literature emerged out of a political vacuum. Jacques Barzun has written that "Berlioz's generation was as much haunted by the guillotine as we are by the death camps." ${ }^{2}$ If this is true, then "guillotine romanticism" can at least in part be explained by the historical and political fact of the Terror, though the executions of ordinary criminals also drew public attention in nineteenth-century France. José Monleón, drawing on Michel Foucault, explains the fantastic obsession with monsters in terms of a "confusion ... in bourgeois epistemology" in which traditional categories of virtue and vice could no longer be distinguished, and explains this confusion as the consequence of class mobility, 
which in turn made it "more difficult to define social relations and to assign the proper images or the appropriate spaces to the different elements of society." ${ }^{.73}$ If he is correct, then the monstrous elements of the victims' ball stories are not purely "literary" but also express the political anxieties of the bourgeoisie. These claims of Barzun and Monleón, though debatable, are surely not entirely false, and one must attribute some political meaning to the victims' ball stories, which bear such striking resemblances to the romantic and fantastic literature in question. Yet this attribution is far from the notion of collective memory as necessarily republican, royalist, Bonapartist, or otherwise discernibly partisan.

If the victims' ball tales grew primarily out of the literary soil of "guillotine romanticism" and the fantastic in the second quarter of the nineteenth century, what accounts for their persistence to this day? As always, one could point to the political goals toward which the stories might be marshaled. For Louis Madelin, who regarded the Revolution as "a tremendous transfer of wealth from one set of persons to another" and "a transfer of property in favour of 'buyer' and of capital for the benefit of "speculators," the bal des victimes epitomized the heartlessness of the successful capitalists. ${ }^{74}$ Similarly, for Mathiez the "bals priviligiés" given "in high society" were simply another indication of the decadence of the bourgeois Revolution and the corruption of Thermidorian society. ${ }^{75}$ Yet an obvious political motivation is missing in the accounts of Joseph Calmette, Marcel Reinhard, not to mention Furet and Richet, who certainly could not be accused of an inveterate hostility to the "bourgeois reaction" of Thermidor and the Directory.

The persistence of the victims' ball stories must be understood in terms of the generally accepted rules of evidence among professional historians. Once a fact becomes "common knowledge" the historian is released from the obligation to cite a source, and only a determined effort to falsify it can dislodge it from the bricolage of generally accepted facts that constitute the historical canon. In this sense the question is less what explains the story's persistence than what could ever eliminate it. Myths such as the bal des victimes are all the more persistent when they serve as an aide-mémoire for a period that historians tend to ignore. The five years between Robespierre and Napoleon, themselves memory markers, are a period that, despite the recent lifting of the professional obligation to disdain the post-Jacobin "reaction," has remained largely unexplored, and has therefore been susceptible to collapse into the "gripping abbreviation" of the victims' ball.

Finally, in addition to repetition of the victims' ball myth in written history, film images have contributed to its persistence in French collective memory. In particular, Abel Gance's 1927 epic Napoleon includes an extended scene of a bal des victimes. Following a sequence in which a man dressed as a jailer apparently reads the names of the condemned, the camera reveals a dancing party in a prison later identified as Carmes. ${ }^{76} \mathrm{~A}$ text frame reads, "In the feverish reaction of life against death all of France was gripped by a desire for pleasure. In a few days 644 balls took place on the graves of the victims of the Terror." 77 A subsequent frame 
explains, "In order to be admitted to the victims' ball one had either to have been in prison or to prove that one had lost one's father, brother, or spouse." This expansion of the rules to include former prisoners was obviously intended to justify Napoleon's presence at the victims' ball. ${ }^{78}$ (Josephine had lost her divorced husband, the marquis de Beauharnais, to the guillotine, but Napoleon had not mourned any relations as a result of the Terror.) At one point a man "decapitates" himself by bursting a balloon in the form of a head, and later an "executioner" acts out the beheading of a woman who kneels with her head protruding through the back of a chair. To be sure, Napoleon deplores the merrymaking of the victimes, and eventually withdraws to another room to play chess. One could therefore read the scene as the ultra right-wing director's legitimization of Napoleon's authoritarian rule over decadent subjects. Yet Gance was not entirely contemptuous of the darcing activity, which was justified by the understandable preference, in his own words, for "life" over "death," and the presence, at least temporarily, of Napoleon. Moreover, Gance sentimentalized the scene by having Josephine show Napoleon the spot in the Carmes prison where she awaited her execution during the Terror. It seems therefore that in addition to politics, Gance considered the value of images that both served to summarize dramatically the multiple tensions in Thermidorian Paris and corresponded in at least some measure to the viewers' "horizon of expectations." ${ }^{\text {"79 }}$ Gance's motivations notwithstanding, his victims' ball scene perpetuated and embellished on the myth in the minds of an incalculable number of viewers, both in the interwar period and since the movie's rerelease by Francis Ford Coppola in the 1980s. ${ }^{80}$

The bal des victimes is therefore not a product of partisan memory. It does not belong to republicans or royalists, legitimists or orleanists, Jacobins or Bonapartists, communists or fascists, but rather to a larger mnemonic community concerned with recounting the story of the French Revolution. This recounting, moreover, operates within a Carlylian tradition according to which the Revolution is an orgiastic moment of chaos from which the great man (Napoleon) emerges. As such, it provides a means of escaping politics, and indeed, in historiographic terms, the politics of interpretation.

\section{Notes}

I am grateful to Patrice Higonnet, Daniel Gordon, Caroline Ford, Stuart Semmel, Carlo Severi, and Suzanne Desan for their comments and suggestions on various drafts of this essay. I also wish to thank the members of the editorial board of Representations, who, in their comments on an earlier version of this paper, noted the lack of contemporary documentation for the bals des victimes and encouraged me to think of them as a phenomenon of collective memory rather than a social fact of Thermidorian and Directory Paris. They thereby prevented me from "falling victim" to the myth. Finally, 
I wish to thank the Deutsche Forschungsgemeinschaft for the generous financial support that made the revisions possible.

1. Thomas Carlyle, The French Revolution: A History (1837; reprint London, 1925), 2:366.

2. Archibald Alison, History of Europe from the Commencement of the French Revolution in M.DCC.LXXXIX. to the Restoration of the Bourbons in M.DCCC.XV. (1835-42; reprint, Edinburgh, 1847), 5:93. Alison's account was cited by Frederick Shoberl, the translator and editor of Adolphe Thiers, History of the French Revolution (Philadelphia, 1848), $3: 151 \mathrm{n}$.

3. 'Théophile Lavallée, Histoire des français depuis le temps des gaulois jusqu'à nos jours (183840; reprint, Paris, 1874), 4:199. Unless otherwise noted, all translations are my own.

4. Jules Michelet, La révolution, vol. 6 of Histoire de France, ed. Claude Mettra (Lausanne, 1967), 436. Louis Blanc, Histoire de la révolution française (Paris, 1862), 12:94, 95.

5. Edmond et Jules de Goncourt, Histoire de la société française pendant le directoire (Paris, 1855), 139, 140.

6. A[Iphonse] Aulard, The French Revolution: A Political Hislory, 1789-1804, trans. Bernard Miall (New York, 1965), 240.

7. Albert Mathiez, La réaction thermidorienne (Paris, 1929), 106.

8. Louis Madelin, The French Revolution (1923-38; reprint, New York, 1967), 445.

9. Joseph Calmette, Les rérolutions (Paris, 1952), 251 n; Marcel Reinhard, ed., Histoire de France (Paris, 1954), 2:139; Norman Hampson, A Social History of the French Revolution (London, 1963), 240; François Furet and Denis Richet, La révolution française (Paris, 1973), 278-79; André Castelot, La France révolutionnaire et romantique (Paris, 1975), 122; Martyn Lyons, France Under the Directory (Cambridge, 1975), 64; Françoise Wagener, Madame Récamier (Paris, 1986), 44; Jean Tulard, Jean-François Fayard, and Alfred Fierro, eds., Histoire et dictionnaire de la révolution française, 1789-1799 (Paris, 1987), 557; and Jean Favier, ed., Chronique de la révolution 1788-1799 (Paris, 1988), 456.

10. Aulard, French Revolution, 240.

11. Alphonse Aulard, Paris pendant la réaction thermidorienne et sous le directoire: Recueil de documents (1899; reprint, New York, 1974), 5 vols. The anthology does include an excerpt from a 1799 issue of the Courrier républicain, in which it is scornfully noted that the son of a man who had been killed in the September massacres of 1792 was seen dancing with the daughter of a man who had been implicated in the atrocity. Yet the report says nothing about a "victims' ball"; Le courrier républicain, 3 frimaire An V, cited in Aulard, Paris pendant la réaction, 3:581.

12. I am grateful to Meredith Alexander for her thorough search of the petites affiches (full title: Affiches, annonces et avis divers où Journal général de France) from August 1794 to mid-December 1795.

13. Le spectateur du nord, journal politique, littéraire et moral. Janvier, fézrier et mars 1797 . Tome Premier. Hambourg, [1797], 493, 493 n.

14. Le censeur dramatique 1 (1797): 74.

15. [Louis-Sébastien] Mercier, Le nouveau Paris (Brunswick, 1800), 3:26. Mercier was a source for Louis Blanc, who cited him but appears to have plagiarized his phrase concerning "des jours de danses où il s'agissoit de valser, de boire et de manger à coeurjoie." Blanc wrote nearly verbatim of "des jours où il s'agissait de valser, de boire et de manger à coeur-joie"; Révolution française, 12:94-95.

16. "Tableau des bals d'hiver," in Almanach des gens de bien, ou Etrenne à la gaité française (Paris, 1798), 159-64. Tableau général du goût, des modes el costumes de Paris, par une société d'artistes et gens de lettres, vol. 1, no. 3, I brumaire An VII, 61-70.

17. Charles Henrion, Les incroyables el les merveilleuses, ouvrage impitoyable (Paris, An V).

18. An earlier "memory" of the victims' ball was recorded in [Etienne de Jouy], Lhermite 
de la chaussée-d'Antin, ou observations sur les moeurs et les usages parisiens au commencement du xixe siècle (Paris, 1816), 3:22.

19. [Philippe Paul Comte de Ségur], Histoire et mémoires par le général CIom]te de Ségur membre de l'Académie française (1825; reprint, Paris, 1873), 1:143.

20. Antoine Caillot, Mémoires pour servir à l'histoire des moeurs et usages des français, depuis les plus hautes conditions, jusquaux classes inferieures de la société, pendant le regne de Louis XVI, sous le Directoire exécutif, sous Napoléon Bonaparte, et jusqu'à nos jours (Paris, 1827), $1: 243-44$.

21. Mlle M. A. Le Normand, Mémoires historiques et secrets de l'Impératrice Joséphine (Paris, 1827), 1:410 n-411 n.

22. Blanc, Révolution française, $12: 95 \mathrm{n}$; Charles Nodier, Souvenirs et portraits, vol. 1 of Oeurres complètes (Paris, 1833), 75.

23. A[ntoine]-V[incent] Arnault, Souvenirs d'un sexagénaire (Paris, 1833), 2:303-4. The coiffure à la victime was mentioned in numerous memoirs. According to the duchesse d'Abrantès, this haircut was the unintended invention of Madame Tallien. She reported that during the Terror "most of the women in prison, wishing to save the treasure of their hair to bequeath to those they loved, took it upon themselves to cut it before the executioner had the right." Upon their sudden release from prison in Thermidor, "they found themselves with short hair." When Madame Tallien saw that the short haircut became her, according to D'Abrantès, she kept it, and the fashionable women of Paris quickly had their hair cropped à la victime; Laure Junot, duchesse d'Abrantès, Histoire des salons de Paris: Tableaux et portraits du grand monde, sous Louis XVI, le Directoire, le Consulat et l'Empire, la Restauration, et le regne de Louis-Philippe Ier (Paris, 1838), 3:95-96. Jacques-Antoine Dulaure, who did not mention victims' balls, recalled the coiffure à la victime as one of the "signs of ralliement" among "Thermidorian youth"; Esquisses historiques des principaux événements de la Révolution française, depuis la convocation des états-généraux jusqu'au rétablissement de la maison de Bourbon (Paris, 1824), 3:396. Pierre-René Choudieu similarly associated the coiffure à la victime with the jeunesse dorée, but said nothing about victims' balls; G[eorges] Guénin and J[oseph] Nouaillac, L'histoire d'après les témoignages des contemporains: L'ancien régime et la rézolution, 1715-1800 (Paris, 1921), 373-74. G. Touchard Lafosse wrote that "women wore their hair à la victime" but said nothing about men's hairstyles and did not mention victims' balls; La Rétolution, l'Empire et la Restauration; ou 178 anecdotes historiques dans lesquelles apparaissent, pour des faits peu connus, 221 contemporains français et étrangers, recueillies et rédigées par G. Touchard Lafosse (Paris, 1828), 109. Georges Duval claimed that the name of the short haircut was changed to coiffure $\dot{a}$ la Titus "to make people forget [the hairstyle's] origin" at the bal des victimes; Souvenirs thermidoriens (Paris, 1844), 2:81. But I have not been able to find any references to a "victims' haircut" in Thermidorian or Directory sources, whereas the term coiffure à la Titus was common. It seems, therefore, that the term "victims' haircut" originated in the $1820 \mathrm{~s}$.

24. D'Abrantès, Histoire des salons, 3:95-100.

25. [Armand François] Comte d'Allonville, Mémoires secrets de 1770 à 1830 (Paris, 1841), $83-84$.

26. Duval, Souvenirs thermidoriens, 2:66-85. E. Lairtullier, who did not mention victims' balls, wrote vaguely that "young people" greeted each other "by inclining their head once and brusquely, as if it were falling, in allusion to that sort of punishment which one was almost used to"; Les femmes célèbres de 1789 à 1795, et leur influence dans la révolution, pour servir de suite et de complément à toutes les histoires de la révolution française (Paris, 1840), 2:296. Louis Blanc also noted the "victims' salute" in Révolution française, 12:94-95. More recently, it has been reported in Favier, Chronique de la Révolution, 456. 
27. Baronne de V[audey], Souvenirs du Directoire et de l'Empire (Paris, 1848), 7, 8. J. G. Millingen, Recollections of Republican France, From 1790 to 1801 (London, 1848), 324.

28. François-Joseph Talma, Mémoires de F.J. Talma écrits par lui-même. Ét receuillis et mis en ordre sur les papiers de sa famille par Alexandre Dumas (Paris, 1850), 4:212-13.

29. A. Richard Oliver, Charles Nodier: Pilot of Romanticism (Syracuse, N.Y., 1964), 13, 14.

30. In order to gain favor with the July Monarchy after having supported Charles X, Nodier lied about his supposedly close friendship with the Girondins, though he was a fourteen-year-old living in Besançon at the time of their execution. Ibid., 201-2.

31. Even sympathetic biographers have connected d'Abrantès's opium addiction to her chronic shortage of money and consequent need to produce copy for publishers after 1835; Nicole Toussaint Du Wast, Laure Junot, duchesse d'Abrantès (Paris, 1985), 297; and Jean Autin, La duchesse d'Abrantès (Paris, 1991), 289.

32. D'Abrantès, Histoire des salons, 3:96.

33. Bronislaw Baczko, Ending the Terror, trans. Michel Petheram (Cambridge, 1994), 2.

34. One of the best-known critiques of commemorative historiography is François Furet, Interpreting the French Revolution, trans. Elborg Forster (Cambridge, 1981). Among the many other scholars who have studied the political uses to which historical memory has been put are Charles Rearick, "Festivals in Modern France: The Experience of the Third Republic," Journal of Contemporary Hislory 12, no. 3 (1977), 435-60; Pierre Nora, ed., Les lieux de mémoire, 3 vols. (Paris, 1984-1992); Henry Rousso, The Vichy Syndrome: History and Memory in France Since 1944, trans. Arthur Goldhammer (Cambridge, Mass., 1991); and Robert Gildea, The Past in French History (New Haven, Conn., 1994). These scholars are for the most part indebted to Maurice Halbwachs, who argued that memory can only be sustained within "social frameworks"; La mémoire collective (Paris, 1950). For an excellent synthetic essay on recent work on memory in France see Patrick $\mathrm{H}$. Hutton, "The Role of Memory in the Historiography of the French Revolution," in History as an Art of Memory (Hanover, N. H., 1993), 124-53.

35. Mercier, Nouveau Paris, 3:27.

36. Duval, Souvenirs thermidoriens, 2:77.

37. Stewarton, The Female Revolutionary Plutarch (London, 1806), 352-61, emphasis in the original.

38. Caillot saw the "Bal aux victimes" as evidence of a "careless" (léger) national character; Mémoires, 1:243. Le Normand explained the desire to dance at victims' balls as resulting from "a thing inherent to the mores of our nation," and quoted Abbé Pierre Brantôme's claim that the "sons of the Gauls" were "a people as careless (léger) as they are frivolous"; Mémoires historiques et secrets, 1:410 n-411 n. The duchesse d'Abrantès admitted that "the foreigner who had been present at such saturnales could say that our nation is a wicked nation," though she claimed that "this is not the case"; Histoire des salons, 3:99-100.

39. Paul, vicomte de Barras, Mémoires de Barras, membre du Directoire (Paris, 1895-96), 4 vols.; Lazare Carnot, Mémoires historiques et militaires sur Carnot, rédigés d'après ses manuscrits, sa correspondance inédite et ses écrits (Paris, 1824); Louis Marie de La RevellièreLépeaux, Mémoires publiés par son fils sur le manuscrit autographe de l'auteur et suizis des pièces justificatives et de correspondances inédites (Paris, 1895), 3 vols.; Joseph Fouché, duc d'Otrante, Mémoires de Joseph Fouché, duc d'Otrante, ministre de la police générale (Brussels, 1825), 2 vols.; Jean-Baptiste Louvet de Couvray, Mémoires de Louvet de Couvray, député à la Convention nationale, avec une notice sur sa vie, des notes et des éclaircissemens historiques (Paris, 1823); B[ertrand] Barère, Mémoires de B. Barère, membre de la Constituante, de la Convention, du Comité de salut public, et de la Chambre des représentants, publiés par MM. Hippolyte Carnot et David (d'Angers) précédés d'une notice historique, par H. Carnot (Paris, 
1842-44), 4 vols.; Henri Grégoire, Mémoires de Grégoire, ancien évêque de Blois (Paris, 1837); Antoine-Claire, comte Thibaudeau, Mémoires sur la Convention, et le Directoire, par A.C. Thibaudeau (Paris, 1824), 2 vols.

40. Maurice Halbwachs, On Collective Memory, ed., trans., and with intro. by Lewis A. Coser (Chicago, 1992), 60.

41. Nodier, Souvenirs et portraits, 75.

42. Caillot, Mémoires, 1:243. One sees the same sense of abbreviation in Carlyle's remark, "Among the innumerable kinds of Balls, let the hasty reader mark only this single one: the kind they call Victim Balls"; French Revolution, 2:366, emphasis added. Similarly, in 1911 Louis Madelin wrote of Thermidorian pleasures in general, "There was a sort of Sadism in all this enjoyment: the bal des Victimes, at which one of the favourite figures danced simulated the incidents of an execution by guillotine, would suffice in itself to enlighten us as to this"; Louis Madelin, The French Revolution (New York, 1967), 445, emphasis added.

43. Le Normand, Mémoires historiques et secrets, 1:256.

44. The rules governing "victimization" differed in the various accounts. According to the Censeur dramatique, "it was necessary to prove that one's father, mother, grandfather, or grandmother had fallen under the national axe"; Censeur dramatique 1 (1797): 74. Mercier recalled a looser definition of victimization but insisted that all participants had been required "to show a certificate according to which one had lost a father, mother, husband, wife, brother, or sister under the iron of the guillotine." He added that "the death of collaterals did not give the right to participate at such a fete." In other words, cousins, aunts, and uncles did not count; Nouveau Paris, 3:26-27. Caillot reported that spouses of executed persons attended the victims' balls; Mémoires, 1:24344. Nodier only noted that any woman participating was required to be in mourning for "someone in her family"; Souvenirs et portraits, 75. Arnault reported the loose requirement of "proving that one had . . . some victim to mourn"; Souvenirs d'un sexagénaire, 2:304. D'Abrantès claimed that the prospective participant had to declare that "the father, brother, uncle, mother, or finally the aunt had been victims of the Revolution," but mentioned nothing about sisters or uncles; Histoire des salons, 3:99. Le Normand, Mémoires historiques et secrets, 1:410 n-411 n.

45. Le Normand, Mémoires historiques et secrets, 1:410 n-411 n.

46. Carlyle, French Revolution, 2:366; Talma, Mémoires, 4:212-13; Aulard, French Revolution, 240. On the social composition of the "Guilded Youth" see François Gendron, La jeunesse dorée: Episodes de la Révolution française (Sillery, Québec, 1979).

47. On the masculinized character of the Terror see Lynn Hunt, "The Imagery of Radicalism," in Politics, Culture, and Class in the French Revolution (Berkeley, 1984), 52-86.

48. [De Jouy], Hermite de la chaussée-d'Antin, 3:22.

49. Nodier, Souvenirs et portraits, 75, emphasis added. Louis Blanc plagiarized this passage, writing nearly verbatim that "the required costume for a danseuse was that in which her mother or sister had perished, that is to say the red shawl and her hair cut level with her neck; Révolution Française, 12:95 n. Duval also reported the presence of red shawls at the victims' balls; Souvenirs thermidoriens, 2:80-81.

50. D'Abrantès, Histoire des salons, 3:95-100.

51. Duval, Souvenirs thermidoriens, 2:80.

52. Caillot, Mémoires, 1:243-44.

53. Mercier, Nouveau Paris, 3:26, emphasis added.

54. Censeur dramatique 1 (1797): 74. It was customary in eighteenth-century France for children to mourn their parents for six months. John McManners, Deuth and the Enlightenment: Changing Attitudes to Death in Eighteenth-Century France (Oxford, 1981), 59. 
55. Arnault, Souvenirs d'un sexagénaire, 2:303.

56. Georges Bataille, Erotism: Death and Sensuality, trans. Mary Dalwood (San Francisco, 1986), 40-48.

57. Spectateur du nord 1 (1797): $493 \mathrm{n}$.

58. Duval, Souvenirs thermidoriens, 2:69.

59. Ibid., $2: 78$.

60. De V[audey], Souvenirs du directoire, 7-8.

61. [Ségur], Histoire et mémoires, 1:143.

62. According to Daniel Gerould, the term Guillotinromantik, first used by Georg Büchner in Dantons Tod (1835), "aptly characterizes the nightmare vision of a terrifying, yet erotic world ruled by the falling blade dispatching its victims into the existential void"; Guillotine: Its Legend and Lore (New York, 1992), 106. On the guillotine in the fiction of Victor Hugo, Alexander Dumas, Jules Janin, Eugene Sue, and Washington Irving, see ibid., 85-98; 115-28.

63. Oliver, Charles Nodier, 13; and Gary Cummiskey, The Changing Face of Horror: A Study of the Nineteenth-Century French Fantastic Short Story (New York, 1992), 57.

64. Gerould, Guillotine, 85-98; 115-28.

65. Charles Nodier, Lord Ruthwen; ou, Les vampires (1820; reprint, Marseilles, 1978); and Charles Nodier, Le vampire; Le délateur (Geneva, 1990).

66. Tzvetan Todorov, Introduction à la littérature fantastique (Paris, 1970), 46-47.

67. On the practice of mystification see P. L. Jacob, Mystificateurs et mystifiés (Paris, 1875).

68. "Encore un bal des victimes," Charivari, 22 November 1844. I am grateful to Rebecca Spang for this reference.

69. Pierre Alexis, vicomte de Ponson du Terrail, Le bal des victimes (1869; reprint Paris, 1889), 5.

70. Ponson is the first author I have encountered who refers to red ribbons around the necks of "victims," but several twentieth-century historians have also reported the presence of this accessory at the bals des victimes; Calmette, Révolutions, 251; Hampson, Social History, 240; Castelot, France révolutionnaire et romantique, 122; Wagener, Madame Récamier, 44; Favier, Chronique de la Révolution, 456; and Aileen Ribeiro, Fashion in the French Revolution (New York, 1988), 122.

71. Alfred Marquiset, Une merveilleuse (Mme Hamelin), 1776-1851 (Paris, 1909), 56.

72. Jacques Barzun, Berlioz and the Romantic Century, cited in Gerould, Guillotine, 85. It is worth noting that Louis-Hector Berlioz included a "march to the scaffold" in the fourth movement of his programmatic Symphonie fantastique of 1830.

73. José B. Monleón, A Specter is Haunting Europe: A Sociohistorical Approach to the Fantastic (Princeton, N.J., 1990), 54-55.

74. Madelin, French Revolution, 444.

75. Mathiez, Réaction thermidorienne, 106.

76. Marcel Reinhard similarly reported victims' balls at the Carmes prison; Histoire de France, 2:139.

77. Abel Gance apparently relied on the Goncourt brothers, who counted 644 subscription balls in Paris in 1795; Goncourt, Société française pendant le directoire, 141.

78. The claim that former prisoners could participate at victims' balls is repeated in Tulard, Fayard, and Fierro, Histoire et dictionnaire, 557.

79. On the notion of "horizons of expectation" see Hans Robert Jauss, Aesthetic Experience and Literary Hermeneutics (Minneapolis, Minn., 1982), 20-26.

80. I viewed the version of Gance's Napolean presented by Francis Ford Coppola, distributed on video cassette by Atlas Video, copyright 1993. I am grateful to Rory Browne for referring me to the victims' ball scene. 